\title{
RESULTS OF MICROBIOLOGICAL RESEARCH IN THE POLISH PART OF THE MUSKAU ARCH - THE LARGEST AMD ENVIRONMENT IN POLAND - FINAL REPORT
}

\author{
Piotr BOŻĘCKI ${ }^{1}$, Grzegorz RZEPA, Tadeusz RATAJCZAK \\ AGH - University of Science and Technology in Kraków, \\ Faculty of Geology, Kraków, Poland
}

\begin{abstract}
This work presents the results of microbiological investigations carried out in the Polish part of the Muskau Arch. In this abandoned lignite mining area highly acidified Fe-rich waters have been formed as a result of sulphide oxidation. Microbiological tests have shown that all studied groups of microorganisms exhibit both time and spatial variability. The most common group of microorganisms are bacteria Galionella $s p$.
\end{abstract}

Keywords: AMD environment, the Muskau Arch, microbiological variability

\section{INTRODUCTION}

The Muskau Arch is a large glacitectonic belt formed mainly during the Saale glaciation. This horseshoe-shaped structure is open to the north (Fig. 1) and crosses the Polish-German border (from Brandenburg, via Saxony to the Lubuskie Province in Poland). Intense glacitectonics disturbances lifted Miocene lignite beds (as well as co-occurring sands and clays) towards the Earth's surface - making them much easier to exploitation carried out both by underground and open pit methods.

The mining of these deposits was active till the end of the 70-ties of the 20th century. Abandoned excavations have been recently filled with water, forming

\footnotetext{
${ }^{1}$ Corresponding author: AGH University of Science and Technology in Kraków, Faculty of Geology, Geo-physics and Environmental Protection, al. Mickiewicza 30, 30-059 Kraków, Poland; e-mail: pbozecki@agh.edu.pl, tel. +48 126172373
} 
about 110 reservoirs in the so called Anthropogenic Lake District. Many of these lakes, especially in the Łęknica Region, are of the acidotrophic type, characterized by low and very low $\mathrm{pH}$ values (usually below 4.0). This is an effect of the oxidation of sulphide-containing lignite leading to the generation of abundant quantities of sulphuric acid. Numerous ochreous precipitates occur in this area, as a consequence of iron oxidation and hydrolysis in the presence of microorganisms. The main objective of the study is the confirmation of the presence of iron-oxidizing bacteria in the waters of Anthropogenic Lake District, which would justify the role of their metabolism in the ferruginous precipitates formation. The quantitative seasonal variability of their population sizes, depending on changing ambient conditions as temperature, precipitation, insolation etc., have also been estimated.

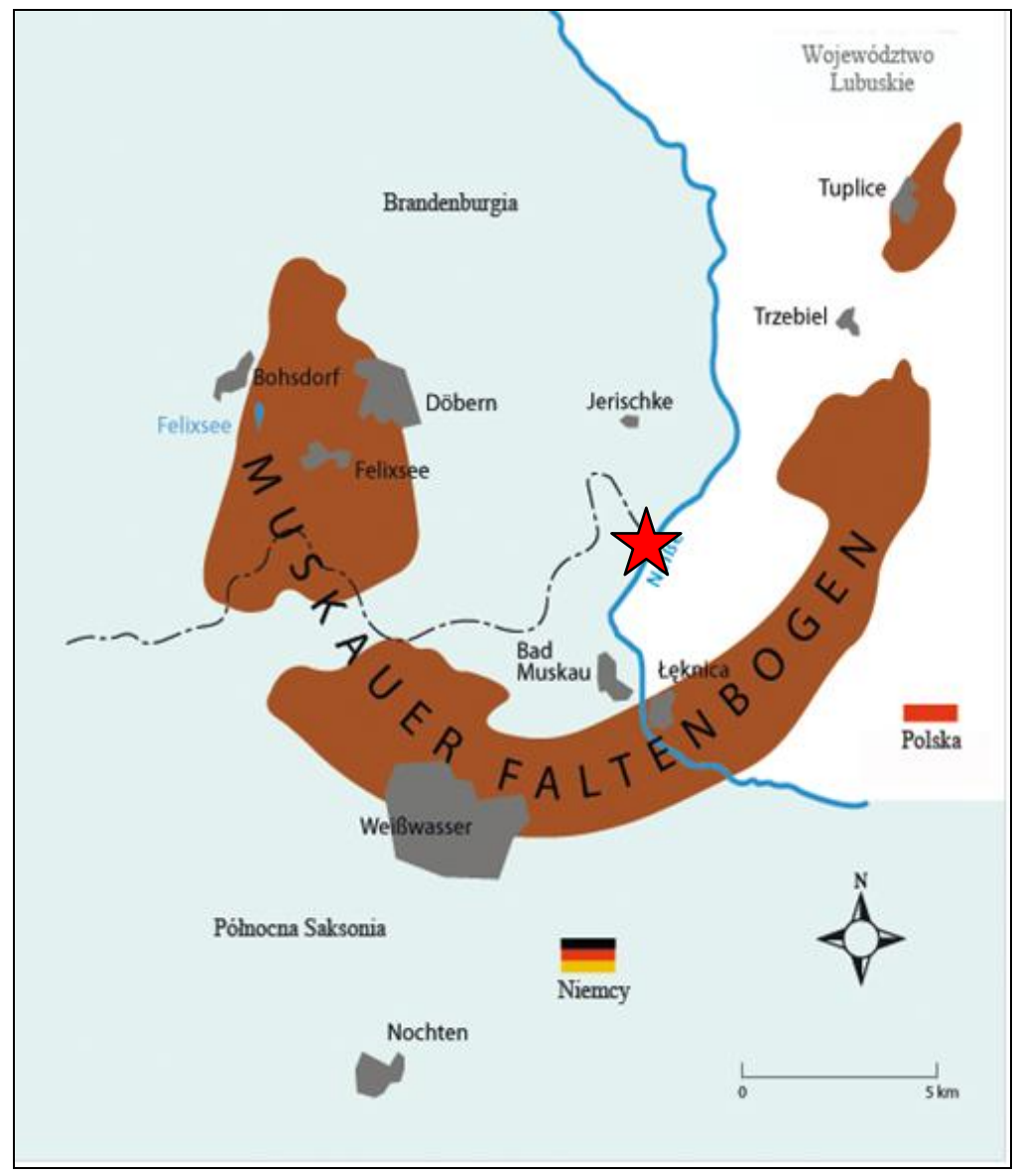

Fig. 1. A sketch map of the Muskau Arch after [4] (modified); red star - the research area 


\section{MATERIALS AND METHODS}

The fieldwork started in July 2009 and ended in September 2010. Water samples from five localities (Fig. 2) were monthly collected and subjected to both microbiological and chemical analyses.

Such parameters as temperature, electrolytic conductivity, redox potential and $\mathrm{pH}$ of the waters were measured in situ. Then the samples were filtered using $0.22 \mu \mathrm{m}$ syringe filters and stabilized with $\mathrm{HNO}_{3}$. The cation concentrations were estimated using ICP-MS ( $\mathrm{Ca}, \mathrm{Mg}, \mathrm{Mn}, \mathrm{Al}, \mathrm{As})$ and FES (Na, K). Total $\mathrm{Fe}$ as well as selected anions $\left(\mathrm{NO}_{2}^{-}, \mathrm{NO}_{3}^{-}, \mathrm{SO}_{4}{ }^{2-}\right)$ were measured by VIS spectrometry and $\mathrm{Cl}^{-}$by titration with $\mathrm{AgNO}_{3}$.

The results of the chemical analysis have already been published by the authors [1-4].

Chosen groups of microorganisms were incubated on Petri dishes or in tubes and then characterized qualitatively and quantitatively after a specific time of incubation. The optimal incubation time and temperature were established as follows:

- 24 hours and $37^{\circ} \mathrm{C}$ for mesophilic bacteria,

- 72 hours and about $23^{\circ} \mathrm{C}$ for psychrophilic bacteria,

- about 10 days and $28^{\circ} \mathrm{C}$ for Heterotrophic Ferruginous Bacteria, Acidithiobacillus ferrooxidans, filamentous bacteria of the genera Leptothrix sp., Gallionella sp. and fungi.

The growth media for these groups of microorganisms were as follows:

- psychro- and mesophilic bacteria: MPA medium [9],

- Heterotrophic Ferruginous Bacteria: medium based on Winogradski receipt [7],

- A. ferrooxidans: $9 K$ medium [8],

- Fungi: the Czapek-Dox medium [7],

- Leptothrix sp.: "Mulder - Van Veen" medium [9],

- Galionella sp.: "Lieske" medium [7].

\section{RESULTS AND DISCUSION}

The results show that the waters are rich in both auto- and heterotrophic microorganisms (Fig. 4, 5, Phot. 1). Their effect on water chemistry is immediate. It results from a change in their physical and chemical environment of the basic parameters such as $\mathrm{pH}$ end Eh.

The results of $\mathrm{pH}$-Eh measurements as well as concentration of iron justify the presence of iron bacteria in the research area. These parameters are compatible 
with the physicochemical conditions [6] essential for the existence and growth of so called iron bacteria (Fig. 3).

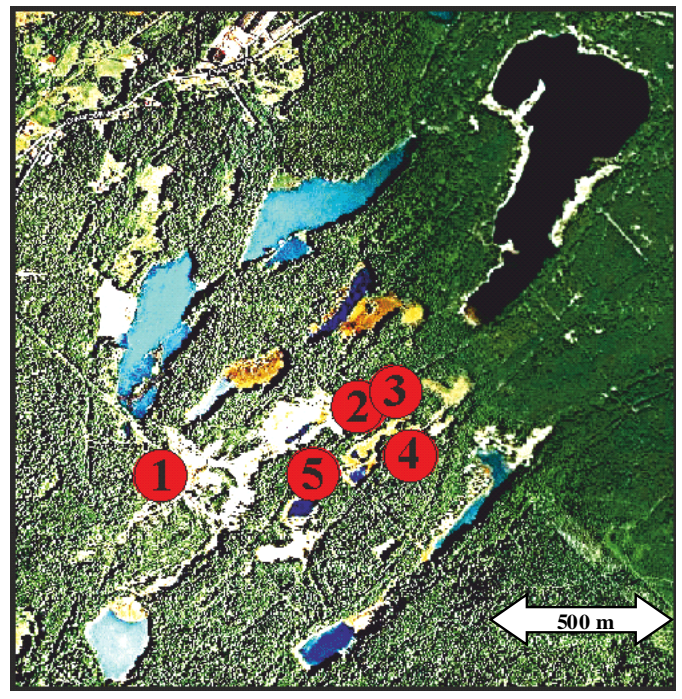

Fig. 2. The location of sampling points (names given by the authors). 1 - "Wyciek źródłowy" ; 2 - "Misa źródłowa I"; 3 -"Misa źródłowa II"; 4 - "Misa źródłowa III"; 5 - "Rozlewisko"

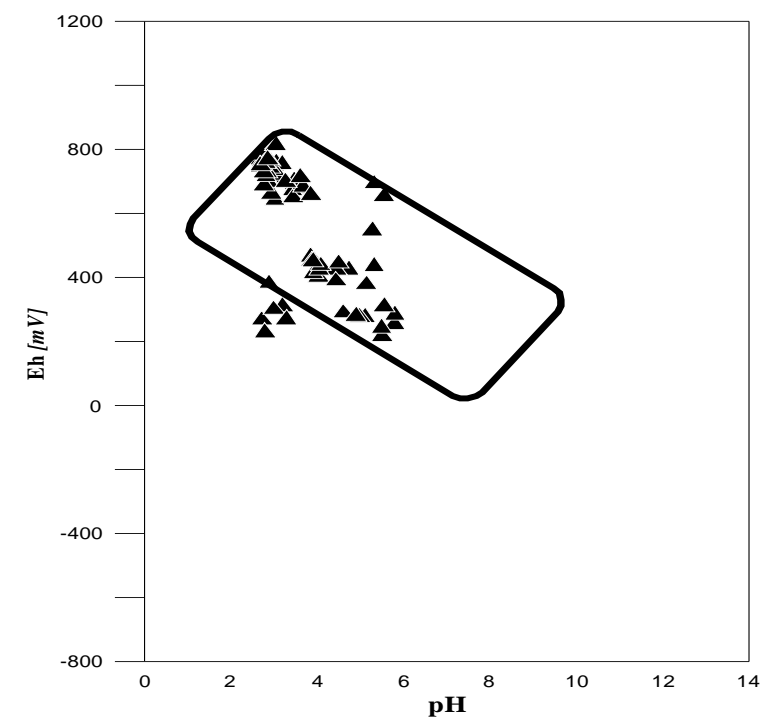

Fig. 3. A projection of $\mathrm{pH}$ and Eh values in the Anthropogenic Lake District waters. black rectangle - the conditions favouring the existence of ferruginous bacteria [6] 


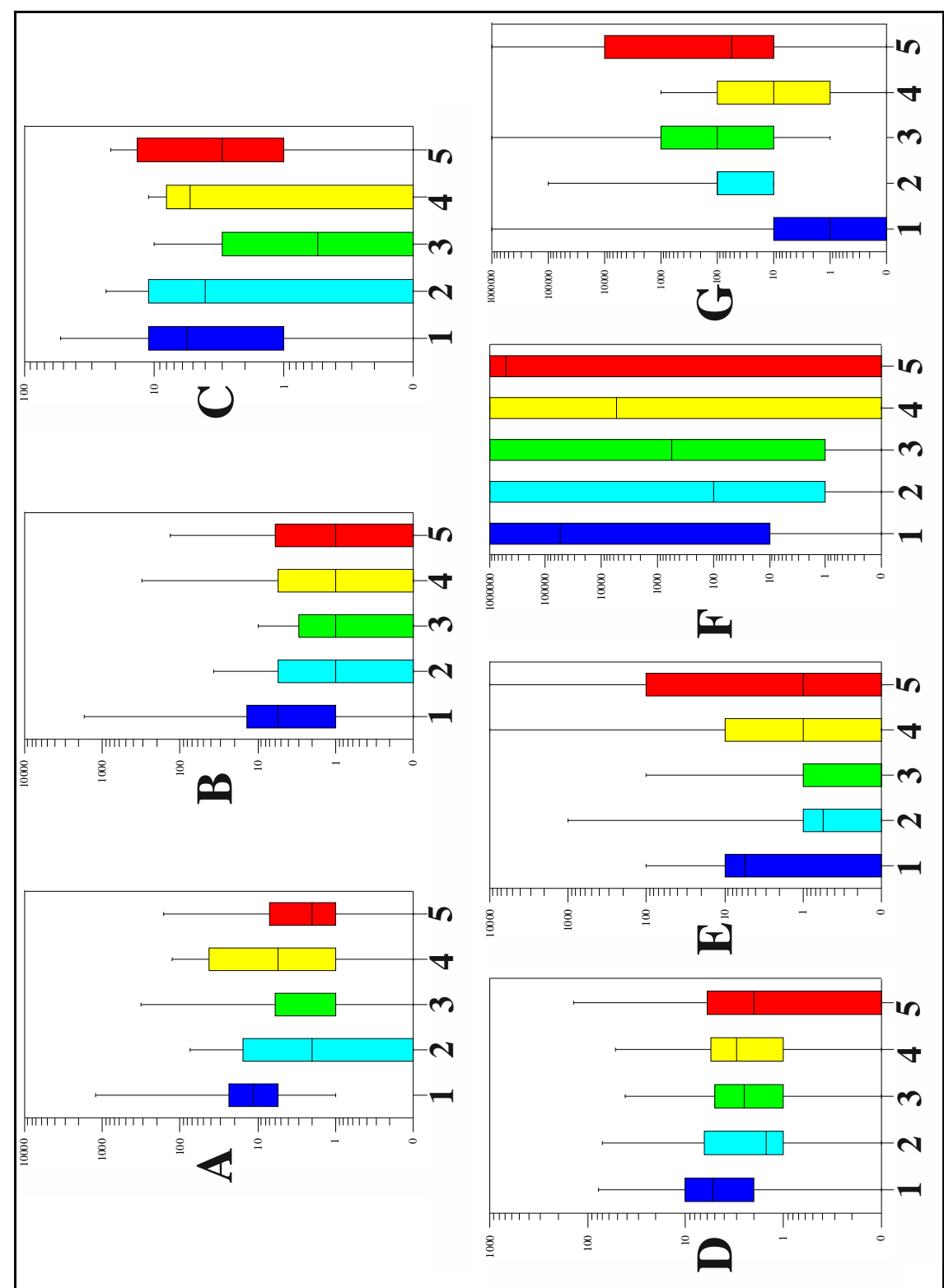

Fig. 4. An illustration of population sizes of microorganisms (measured as amounts of bacteria cells in $1 \mathrm{~mL}$ of the water). A - psychrophilic bacteria; B - mesophilic bacteria; C - fungi; D - Leptothrix sp.; E - Heterotrophic Ferruginous Bacteria; F - Gallionella sp.; G - Acidithiobacillus ferrooxidans; 1-5 - sampling points; 1 - "Wyciek źródłowy"; 2 - "Misa źródłowa I"; 3 - "Misa źródłowa II"; 4 - "Misa źródłowa III"; 5 - "Rozlewisko" 


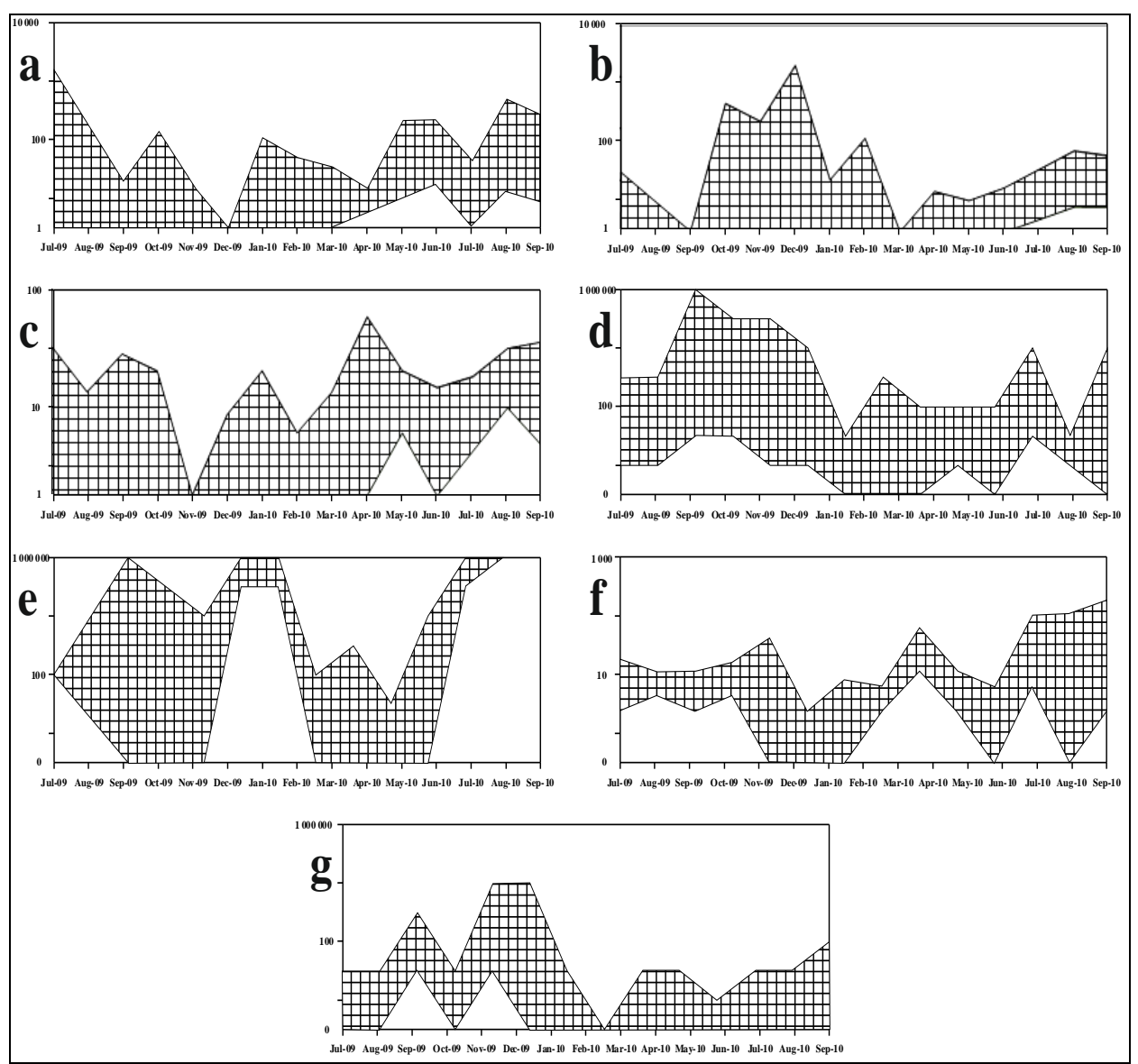

Fig. 5. Seasonal variations of the population sizes of selected groups of microorganisms (the crosshatched area shows the ranges of the values observed in different sampling points); a - psychrophilic bacteria; $\mathrm{b}$ - mesophilic bacteria; $\mathrm{c}$ - fungi;

d - Acidithiobacillus ferrooxidans; e -Galionella sp.; f - Leptothrix sp.; g- Heterotrophic Ferruginous Bacteria

Microbiological analyses showed that the most numerous bacteria in Anthropogenic Lake District waters are filiform variety of Galionella sp. (Fig. 4 - 6). However, it is noteworthy that their population size did not correlate with measured ambient temperature. The explanation of this situation might be as follows: another abundant microorganism in this area is Acidithiobacillus ferrooxidans, which consumes the same nutrients. To win the "competition" these bacteria can even inhibit growth of their population. They are also more sensitive to temperature changes. 


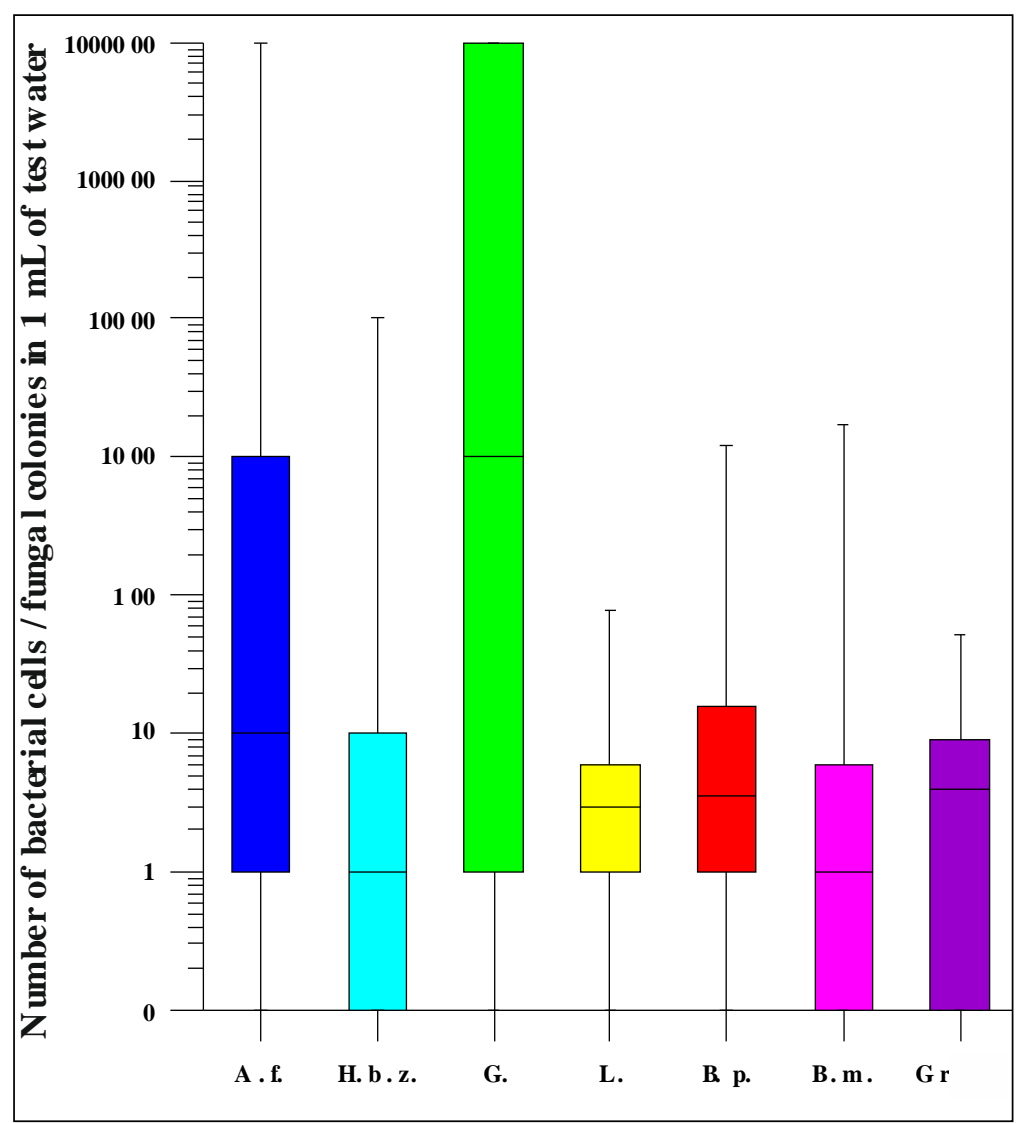

Fig. 6. Total population sizes (from all localities) of microorganisms. Explanations: A. f - Acidithiobacillus ferrooxidans; HBZ - Heterotrophic Ferruginous Bacteria, G. - Galionella sp., L - Leptothrix sp., B. p - psychrophilic bacteria, B. $\mathrm{m}$ - mesophilic bacteria, $\mathrm{Gr}$ - fungi

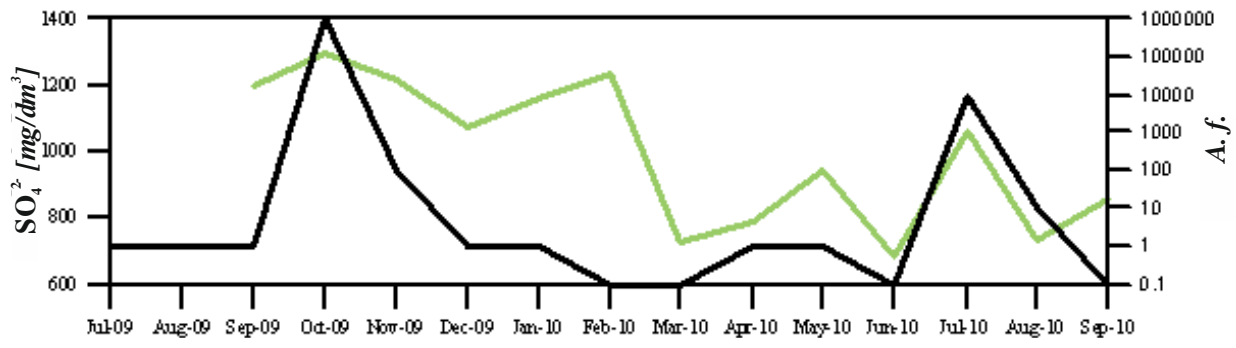

Fig. 7. The variability of sulphate concentration and the Acidithiobacillus ferrooxidans population size in the sampling point "Rozlewisko" 

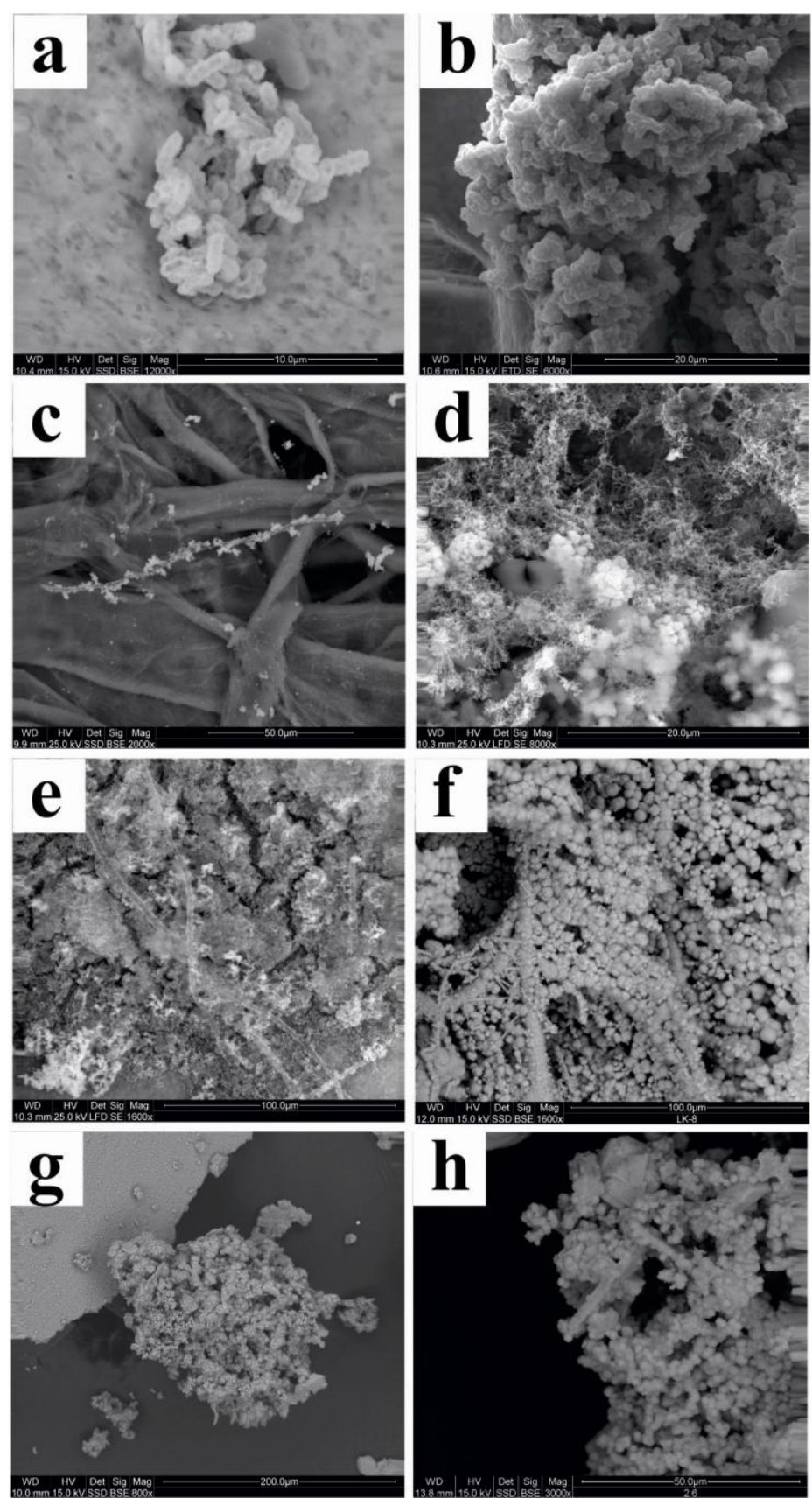

Photo 1. SEM images of isolated bacterial cultures; a, b - Acidithiobacillus ferrooxidans; c - f - Galionella sp.; g, h - Heterotrophic Ferruginous Bacteria 
The performed analyses confirmed the impact of some microorganisms - mainly Acidithiobacillus ferrooxidans and Heterotrophic Ferruginous Bacteria on the processes of iron sulphide oxidation. This is reflected, in inter alia a strong positive correlation between the size of their populations and the sulphate concentration (Fig. 7).

On the basis of the results of this research another conclusion can be drawn - if we consider the population sizes of psychro- and mesophilic bacteria as well as fungi we can say that water in the tested sites exhibits good sanitary conditions. This is certainly true only in terms of microbiological conditions.

\section{ACKNOWLEDGEMENTS}

This work was supported by AGH-University of Science and Technology statutory grant No. 11.11.140.319.

\section{REFERENCES}

1. Bożęcki P., Kotulska M., Rzepa G.:, Variability of water composition in the AMD-type environment: the Eęknica region case study, Mineralia Slovaca 43, 2, 2011 172-173.

2. Bożęcki P., Rzepa G.:, Variability of chemical composition in reservoirs in the Lęknica region (the Muskau Arch, western Poland) and attempt to set the relation between this variation and the microbiological activity, Goldschmidt 2011, August 14-19, 2011 in Prague, Czech Republic, Coference Meterials.

3. Bożęcki P., Rzepa G.:, Wstępne wyniki badań mineralogicznohydrogeochemicznych prowadzonych $w$ rejonie zlikwidowanej kopalni węgla brunatnego „Przyjaźn Narodów” szyb „Babina” w rejonie Lęknicy (SW Polska). Górnictwo Odkrywkowe, Wrocław 2 (2010), 66-69.

4. Bożęcki P., Rzepa R.:, Wstępne wyniki badań zmienności chemizmu kwaśnych wód kopalnianych $z$ rejonu Łęknicy (SW Polska), [in:] Interdyscyplinarne zagadnienia w górnictwie i geologii (eds. W. Ciężkowski, J. Drzymała), Oficyna Wydawnicza Politechniki Wrocławskiej Wrocław, 2010, 113-121,.

5. Kupetz A., Kupetz M., Der Muskauer Faltenbogen, Munechen, Verlag DR. Friedrich Pfeil, 2009.

6. Macioszczyk A., Dobrzański D.: Hydrogeochemia strefy aktywnej wymiany wód podziemnych, Warszawa, Wyd. PWN, 2007.

7. Mrozowska J.:, Laboratorium z mikrobiologii ogólnej $i$ środowiskowej. Gliwice, Wyd. Politechniki Śląskiej, 1999. 
8. POLSKA NORMA PN-C-04615-21:1980 - Woda $i$ ścieki. Badania mikrobiologiczne. Oznaczanie bakterii Thiobacillus ferrooxidans metoda hodowli na pożywce płynnej.

9. Schlegel H. G.:, Mikrobiologia ogólna, Warszawa, PWN, 2003.

\section{WYNIKI BADAŃ MIKROBIOLOGICZNYCH PROWADZONYCH W ZBIORNIKACH KWAŚNYCH WÓD KOPALNIANYCH W POLSKIEJ CZĘŚCI ŁUKU MUŻAKOWA - NAJWIĘKSZYM TEGO TYPU ŚRODOWISKU W POLSCE}

\section{Streszczenie}

W rejonie Łuku Mużakowa prowadzona była eksploatacja m.in. węgla brunatnego. Działalność kopalń w tym rejonie trwała do końca lat 70. XX wieku. Po zakończeniu eksploatacji w obniżeniach terenu powstały liczne zbiorniki wodne, tworzące tzw. pojezierze antropogeniczne. W wyniku utleniania siarczków (głównie pirytu) występujące tutaj wody są bogate $\mathrm{w}$ żelazo oraz charakteryzują się bardzo niskim $\mathrm{pH}$. W pracy przedstawiono wyniki badań mikrobiologicznych wykonywanych w polskiej części tej struktury geologicznej. Stwierdzono, że wszystkie badane grupy mikroorganizmów wykazują zmienność zarówno czasową (wynikającą z pór roku) jak i przestrzenną (wynikająca z miejsca pobrania próbki do badań). Wykazano, iż najliczniejszą grupą mikroorganizmów są nitkowate bakterie z rodzaju Gallionella. Stosunkowo liczne są ponadto bakterie Acidithiobacillus ferrooxidans. Ponieważ obie te grupy mikroorganizmów do swojego wzrostu potrzebują tych samych związków chemicznych ich populacje konkurują ze sobą - nawet kosztem ograniczenia tempa rozwoju populacji własnego gatunku.

Słowa kluczowe: Środowisko AMD, Łuk Mużakowa, zmienność mikrobiologiczna

Editor received the manuscript: 16.04 .2013 